\title{
ZESPÓŁ DWORSKO-PARKOWY W ROMANOWIE HISTORIA I OBECNY STAN ZACHOWANIA
}

\author{
Kamila Lucyna Boguszewska \\ Samodzielna Pracownia Architektoniczna, Politechnika Lubelska \\ Independent Architectural Design Studio, The Faculty of Civil Engineering and Architecture \\ e-mail: kamila_boguszewska@interia.eu
}

\begin{abstract}
Streszczenie: Zespół dworsko-parkowy w Romanowie jest siedzibą rodową rodziny Kraszewskich. W chwili obecnej zabytkowy dwór wraz z trzyhektarowym parkiem pełni funkcję Muzeum Józefa Ignacego Kraszewskiego.

Celem artykułu jest przedstawienie historii oraz stanu zachowania zespołu rezydencjonalnego, jego przekształceń ze szczególnym uwzględnieniem obiektów małej architektury towarzyszących całości.

Do czasów obecnych na terenie parku zachowały się bowiem dwa tego typu obiekty budowlane, którymi są kaplica parkowa fundacji Konstancji Mochorowskiej z 1810 roku oraz eklektyczna brama wjazdowa datowana na pierwszą połowę XIX wieku. W artykule przytoczone zostaną także opisy nieistniejących już obiektów parkowych między innymi neogotyckiej cieplarni oraz samotnej chaty stanowiącej niegdyś element romantycznego założenia.
\end{abstract}

Słowa kluczowe: Muzeum Józefa Ignacego Kraszewskiego w Romanowie, zespół dworsko - parkowy, klasycyzm, środki unijne, restauracja

\section{WSTĘP}

Obecnie w rejestrze zabytków nieruchomych Narodowego Instytutu Dziedzictwa (NID) znajdują się 4834 obiekty rezydencjonalne, zaś w samym województwie lubelskim ich liczba wynosi 270 . Jako obiekty rezydencjonalne rozumiane są tutaj zarówno pałace jak i dwory, choć kryterium ich podziału może być nieraz problematyczne.

Stan zachowania tego typu obiektów jest zróżnicowany. Jedynie $8 \%$ liczby wszystkich dworów znajduje się w stanie dobrym, zaś 38\% wymaga remontu kapitalnego, podobnie kształtuje się sytuacja jeżeli chodzi o budynki pałaców - jedynie 7\% jest w stanie dobrym, $37 \%$ wymaga kapitalnego remontu ${ }^{1}$.

Przedstawione dane nie są optymistyczne. Jeżeli w najbliższym czasie nie zostaną podjęte skuteczne działania mające na celu ochronę, a także konserwowanie architektury rezydencjonalnej z ziem Lubelszczyzny znikną obiekty stanowiące jej kulturowe dziedzictwo.

\section{HISTORIA ZAŁOŻENIA DWORSKO-PARKOWEGO W ROMANOWIE}

Zespół dworsko - parkowy w Romanowie usytuowany jest w odległości około 21 kilometrów od Włodawy i 6 kilometrów od miejscowości Hanna. Majątek ten jest siedzibą rodową rodziny Kraszewskich, choć pierwotnie Romanów należał do rodu Sanguszków ${ }^{2}$, fundatorów drewnianego pałacu oraz założenia ogrodowego powstałego około 1540 roku³ . Poprzez

1 http://www.nid.pl/pl/Informacje_ogolne/Zabytki_w_Polsce/rejestr-zabytkow/zestawienia-zabytkow-nierucho$\mathrm{mych} /, 10.10 .2015 \mathrm{r}$.

2 W skład dóbr, kiedy właścicielami majątku była rodzina Sapiehów wchodziły wsie: Czeputka, Wygnanka, Sosnówka. (Za: R. Aftanazy, Dzieje rezydencji na dawnych kresach Rzeczypospolitej, województwo brzesko - litewskie nowogródzkie, t. 2, Zakład Narodowy im. Ossolińskich, Wrocław 1992, s. 123).

3 F. Sulmierski, B. Chlebowski, W. Walewski, Stownik geograficzny Królestwa Polskiego i innych krajów stowiańskich, Warszawa 1880-1904, s. 720-721. 
koligacje rodzinne ${ }^{4}$ majątek przeszedł w 1623 roku w ręce Leszczyńskich następnie zaś rodziny Sapiehów5.

W 1801 roku zespół pałacowo - parkowy nabyli Błażej i Anna z Nowomiejskich Malskich h. Nałęcz. Dwór wybudowany przez Błażeja Malskiego oparty został na istniejących osiemnastowiecznych sklepieniach krzyżowo-żebrowych, co wraz z kanałami i wałami zachowanymi w parku świadczyło o charakterze obronnym pierwotnego założenia6. Pięć lat później na miejscu drewnianego dworu wzniesiono murowany klasycystyczny pałac. Parterowa, dziewięcioosiowa bryła oparta była na planie prostokąta. Po pożarze w 1858 budynek został ponownie odbudowany. W tym czasie znacznie zmodyfikowano architekturę pałacu. Środkowy ryzalit otrzymał dodatkowe piętro, ganek zastąpiono czterokolumnowym portykiem wspierającym balkon zaś od strony ogrodu dodano taras. [Ryc. 1, Ryc. 2]. Budynek, oparty na prostokątnym, planie posiadał symetryczny podział z centralnie umieszczoną kwadratową sienią i dużym salonem usytuowanym od strony ogrodu?

Podczas gdy siedziba zmieniła swój wygląd park towarzyszący dworowi nie zmienił charakteru. Właściciele nie ulegli bowiem modzie na angielszczyznę $e^{8}$ Całe założenie zwane włoskim 9 opierało się na barokowym, symetryczym podziale na kwatery. Pałac poprzedzał dziedziniec porośnięty trawą otoczony był budynkami oficyn i stajniami. Właściwy ogród usytuowano za pałacem.

Prostokątne założenie, usytuowane na osi alei jodłowej, rozdzielone było giętymi szpalerami grabowymi tworzącymi zacienione aleje. Całość dopełniał budynek cieplarni10 ${ }^{10}$ kaplica.

4 małżeństwo córki księcia Romana Sanguszki - Teodory z Andrzejem Leszczyńskim h. Wieniawa oraz wnuczki Anny Radzimińskiej z Rafałem Leszczyńskim.

5 R. Aftanazy, Dzieje..., op. cit., s. 123-124.

6 Ibid., s. 123.

7 Ibid., s. 125.

8 Ibid., s. 123.

9 Ibid., s. 123-125.

10 R. Aftanazy stwierdza, że istniejące cieplarnie posiadały charakter neogotycki. Potwierdzają to zachowane rysunki J. Kraszewskiego, gdzie można rzeczywiście zauważyć strzelistą wieżyczkę oranżerii zwieńczoną stromym dwuspadowym dachem. Na rysunku widoczne jest także ostrołucznie zakończone okno i czteroliść będący ozdobą wykonaną w tynku bądź oknem-rozetą. Niestety ze względu na charakter zachowanej ikonografii nie jest możliwym określenie funkcji tego elementu architektonicznego. W mniemaniu ówczesnych możnych architektura neogotycka była najodpowiedniejszym stylem pawilonów ogrodowych ze względu na jej romantyczny charakter i nawiązania do średniowiecza, co było pożądane w parkach krajobrazowych. Na Lubelszczyźnie istniał szereg cieplarni o tym charakterze - Witulin, Posadów. Ze względu na charakter obiektu na rysunku J. Kraszewskiego warto przyjrzeć się architekturze nieistniejącej oranżerii w Posadowie opisanej przez J. Żywickiego w książce Architektura Neogotycka na Lubelszczyźnie. Oranżeria datowana była podobnie jak oranżeria w Romanowie na połowę XIX wieku. Cieplarnia posiadała formę budynku z rotundą w narożu, przekrytej stożkowym dachem. Elementami gotyckimi było ostrołuczne zakończenie otworów okiennych, a także motyw rybich pęcherzy i wieloliści w żeliwnych ramach okien. (Za: J. Żywicki, Architektura neogotycka na Lubelszczyźnie, Regionalny Ośrodek Studiów i Ochrony Środowiska Kulturowego w Lublinie idea Media, Lublin 1998 s. 282). Stąd stwierdzenie autorki artykułu, że czteroliść widoczny na rysunku J. Kraszewskiego może być elementem otworowania budynku. 


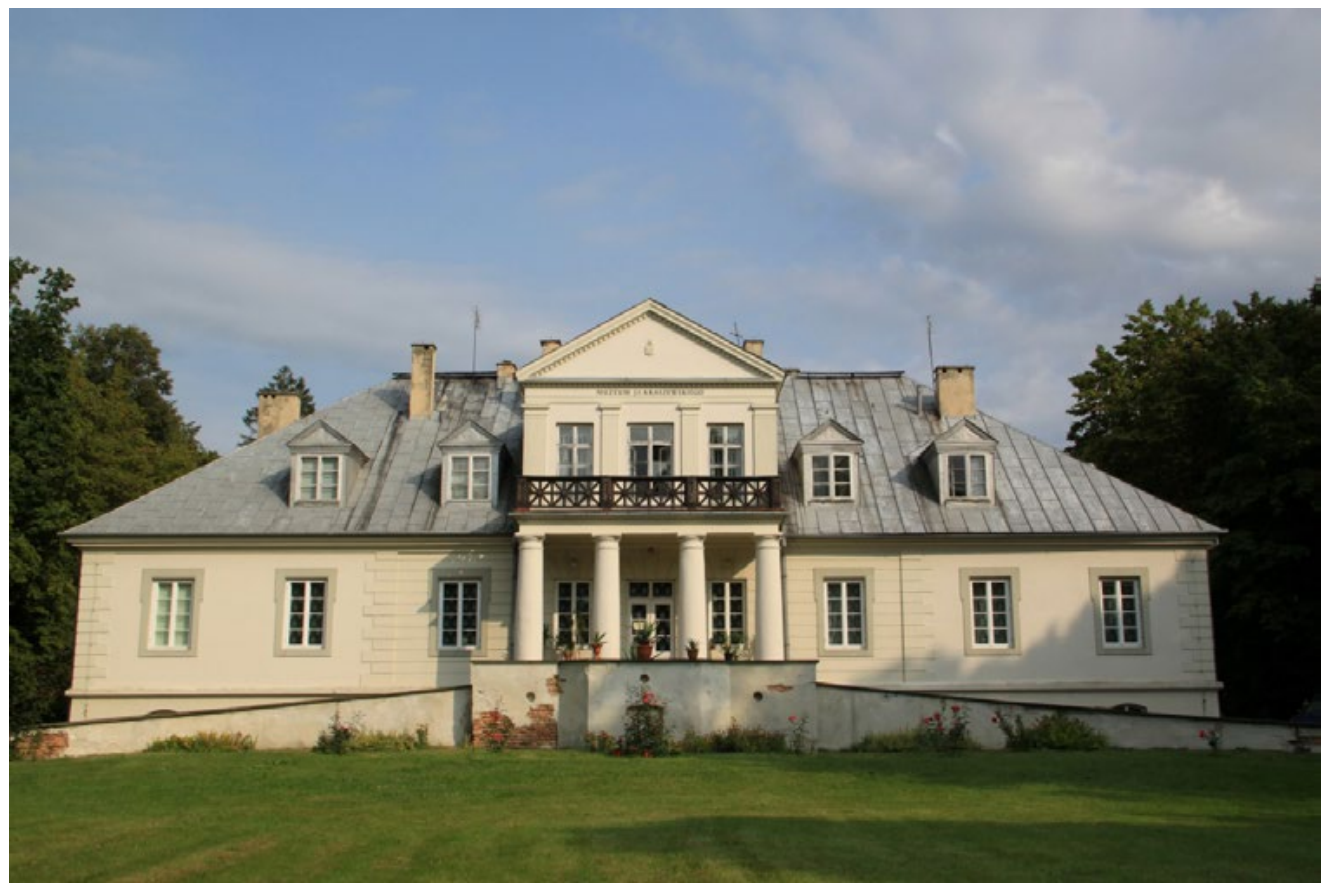

Ryc. 1. Pałac w zespole rezydencjonalnym w Romanowie. Fot. autor, (2011)

Fig.1. The building of palace in Romanow complex. Photo by author, (2011)

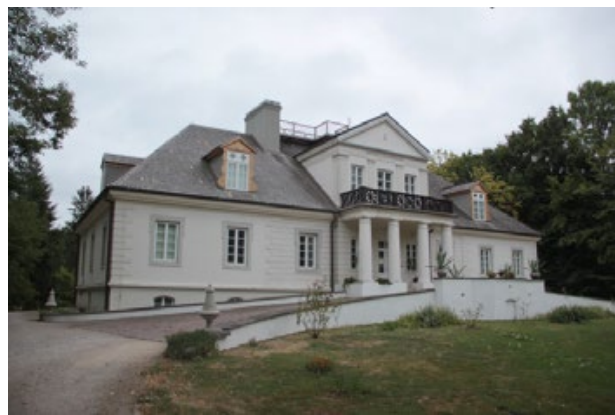

a

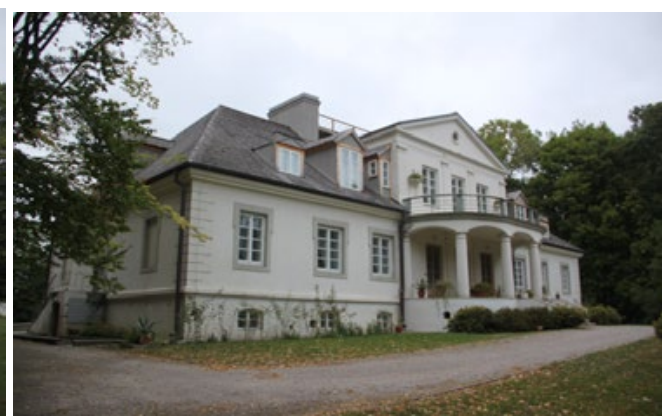

b

Ryc. 2. Romanów, a - fasada pałacu po restauracji, b - elewacja ogrodowa pałacu po restauracji . Fot. autor, (2015)

Fig. 2. Romanow a - facade of the palace after rehabilitation, $b$ - garden elevation of palace after rehabilitation. Photo. author, (2015)

\section{EKLEKTYCZNA BRAMA WJAZDOWA}

W połowie XIX wieku miejsce starej bramy ${ }^{11}$ zajęła nowa o charakterze romantycznym, poprzedzona mostem z kamienną balustradą. Ówczesna brama zachowała się do chwili obecnej.

11 O stanie zachowania bram i kordegard w zespołach dworskich i pałacowych województwa lubelskiego pisały E. Przesmycka i K. Boguszewska w Tece Komisji Architektury, Urbanistyki i Studiów Krajobrazowych, PAN Lublin, 2011, s. 117-125. W artykule opisano także eklektyczną bramę wjazdową w Romanowie. 


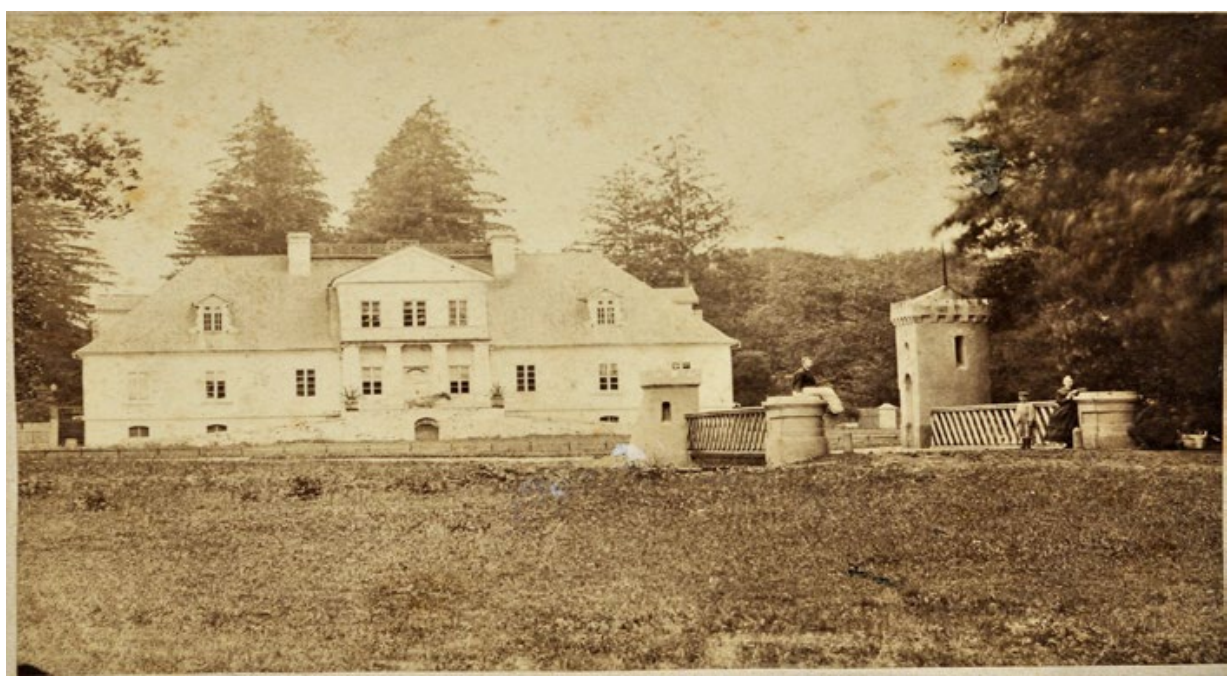

Ryc. 3. Eklektyczna brama wjazdowa, w tle pałac rodziny Kraszewskich I połowa XIX w., zbiory Muzeum Józefa Ignacego Kraszewskiego w Romanowie

Fig. 3. Eclectic gate, in the background palace of Kraszewski family. Source: The Museum Jozef Ignacy Kraszewski in Romanow

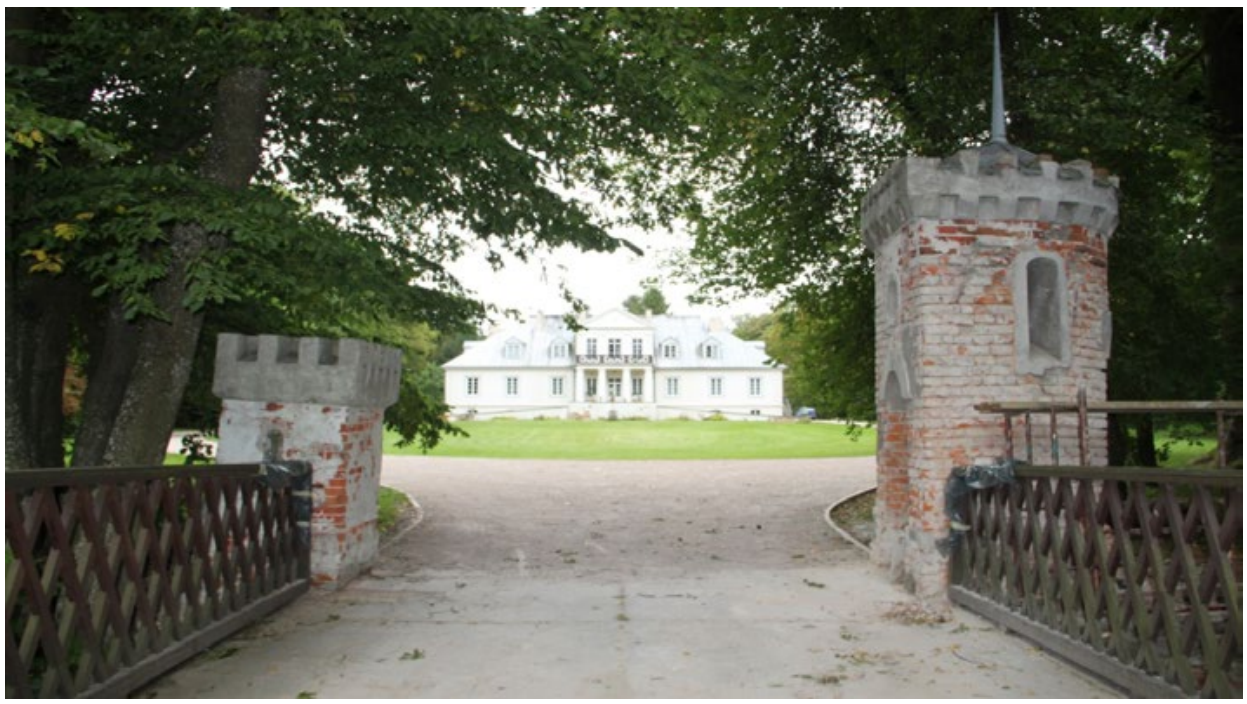

Ryc. 4. Eklektyczna brama wjazdowa, w tle pałac rodziny Kraszewskich. Fot. autor, (2011) Fig. 4. Eclectic gate, in the background palace of Kraszewski family. Photo by autor (2011)

Obiekt datowany jest na I połowie XIX wieku (1840-1850). Brama składa się z półkolistej baszty posiadającej okienka strzelnicze, arkadowe wejście oraz okulus. Jej mur zwieńczony jest krenelażem zaś przekrycie stanowi wielopołaciowy daszek zwieńczony iglicą. Po stronie północnej umieszczono czworoboczny słup bramny z krenelażem, wsparty na skośnej szkarpie $^{12}$. W latach 2007-2013 w ramach projektu pt. Restauracja zespolu dworsko-parkowego

12 Katalog zabytków sztuki w Polsce, województwo lubelskie, powiat włodawski, T. VIII, z. 18, Instytut Sztuki PAN, 1975, s. 37. 
w Romanowie będacego siedziba Muzeum Józefa Ignacego Kraszewskiego została przeprowadzona kompleksowa odnowa poszczególnych obiektów zespołu ${ }^{13}$. Oprócz pałacu restauracji poddana została także eklektyczna brama, [Ryc. 4., Ryc. 5, Ryc. 6], która zyskała dawną świetność [Ryc. 3].

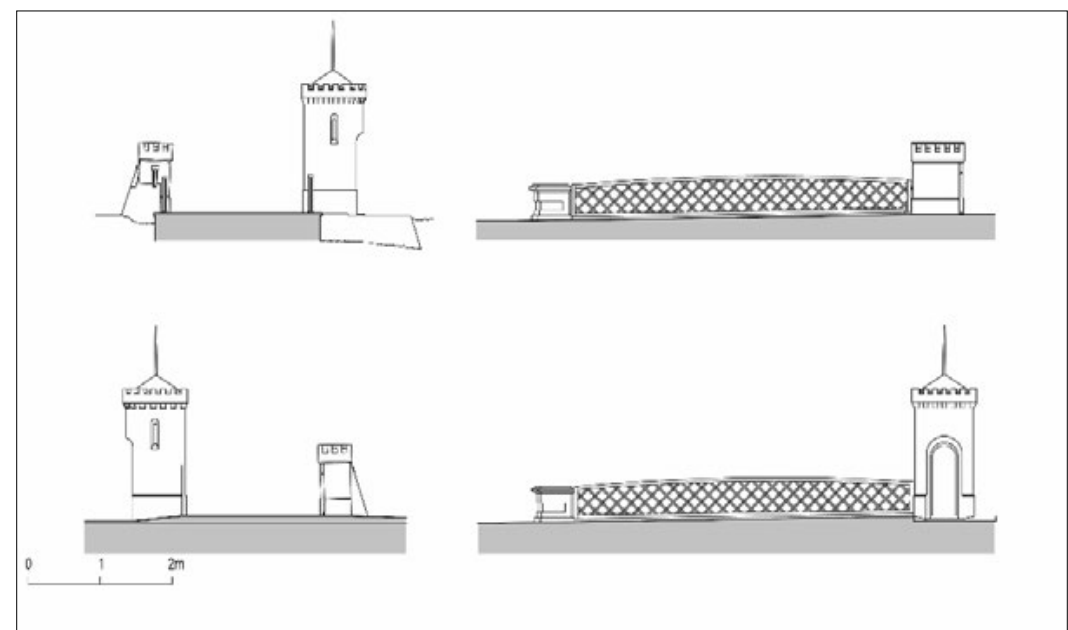

Ryc. 5. Romanów most. Oprac. autor, (na podstawie: A. Stanilewicz, H. Dołęgowski, Prace remontowe przy obiekcie stupy bramne (stupy bramne i dwie wieżyczki), lipiec 2010)

Fig.5. Romanow bridge. Prepared by author, (based on A. Stanilewicz, H. Dołęgowski,

Prace remontowe przy obiekcie stupy bramne (stupy bramne i dwie wieżyczki), lipiec 2010

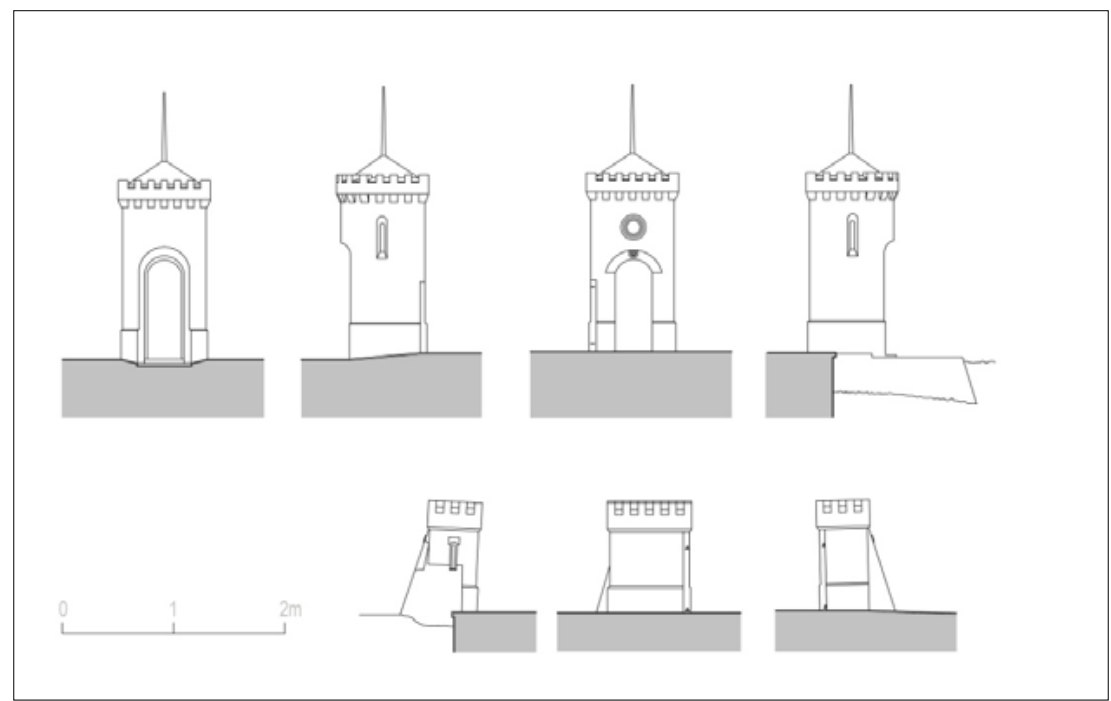

Ryc. 6. Romanów most. Oprac. autor, (na podstawie: A. Stanilewicz, H. Dołęgowski, Prace remontowe przy obiekcie stupy bramne (stupy bramne i dwie wieżyczki), lipiec 2010

Fig.6. Romanow bridge. Prepared by author, (based on A. Stanilewicz, H. Dołęgowski,

Prace remontowe przy obiekcie stupy bramne (stupy bramne i dwie wieżyczki), lipiec 2010

13 Informacja dotycząca projektu pochodzi ze strony Muzeum Józefa Ignacego Kraszewskiego, http://www.muzeumkraszewskiego.pl/historia-dworu/, 10.10.2015 r. 
Obecnie park, o oryginalnym układzie przestrzennym, posiada powierzchnię trzech hektarów. Wśród gatunków drzew przeważających największy udział mają Fraxinus Excelsior, Alnus glutinosa, Acer platanoides oraz Robinia pseudoacacia. ${ }^{14}$

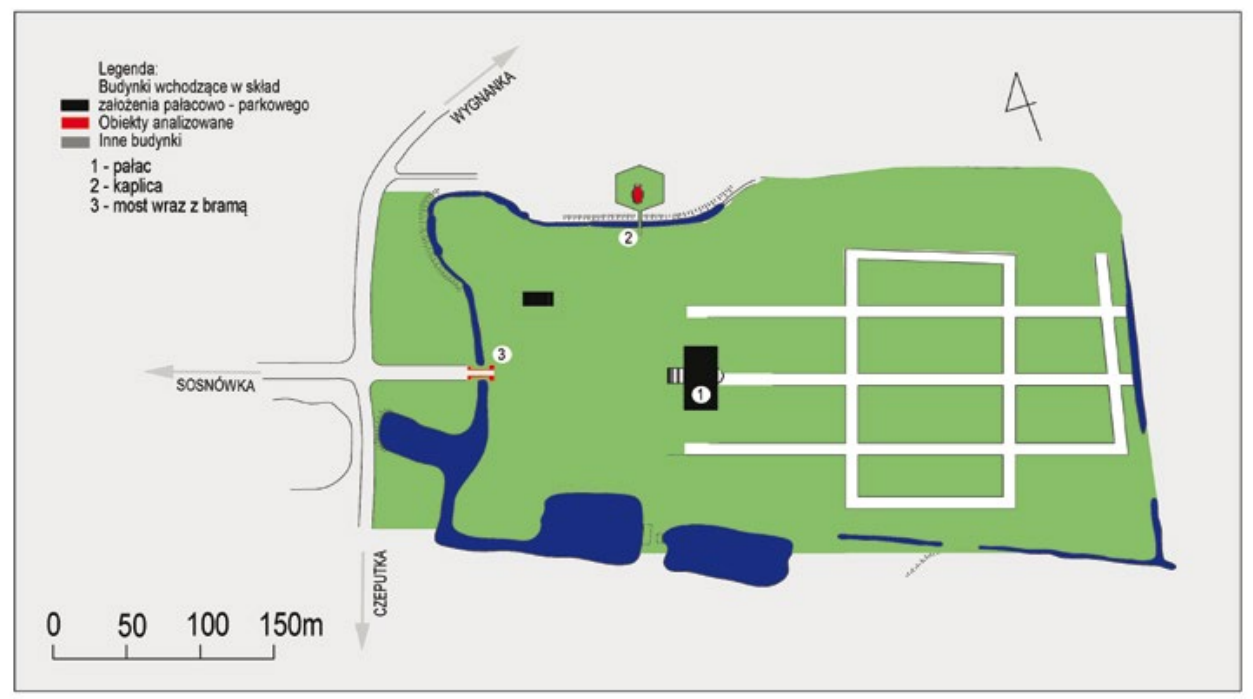

Ryc. 7. Romanów, schemat planu zespołu pałacowo-parkowego w obecnych granicach. Oprac. autor

Fig.7. Romanow, schematic plan of the palace-park complex (current borders). Prepared by author

\section{KAPLICA PARKOWA}

$\mathrm{Na}$ granicy parku, w jego północnej części, zlokalizowana została klasycystyczna kaplica (wzniesiona równolegle $\mathrm{z}$ pałacem) ufundowana przez Konstancję Mochorowską ${ }^{15}$.

Kaplica p.w. Św. Anny, umiejscowiona została za fosami. Z założeniem dworsko parkowym została skomunikowana za pomocą mostu. [Ryc.8] .

Kaplica ufundowana została w roku $1810^{16}$. Autorem projektu był Jakub Kubicki.

Pierwotnie, świątynia miała pełnić funkcję kaplicy grobowej. Jednakże nigdy do tego nie doszło ${ }^{17}$.

14 D. Fijałkowski, M. Kseniak, Parki wiejskie Lubelszczyzny stan ochrona i rewaloryzacja biocenotyczna, PWN, Warszawa 1982, s. 126.

15 W roku 1859 Zofia Malska wniosła Romanów w posagu Janowi Kraszewskiemu herbu Jastrzębiec. Nastepnymi dziedzicami Romanowa byli: Kajetan Kraszewski - malarz, rzeźbiarz, literat oraz astronom, brat Józefa Ignacego Kraszewskiego, jego starszy syn Bogusław oraz młodszy Krzysztof Kraszewski.

16 J. Petera-Górak podaje datę powstania kaplicy na rok 1806. (Za: J. Petera-Górak, Petera-Górak J., Kaplice i figury w rezydencjach ziemiańskich i parkach dworskich na Lubelszczyźnie, [w:] Ziemiaństwo na Lubelszczyźnie, Materiały II sesji naukowej zorganizowanej w Muzeum $w$ Zamoyskich $w$ Kozłówce 22-24 maja 2002, opracowała Róża Maliszewska, Muzeum Zamoyskich w Kozłówce 2003, s. 270).

17 Ibid., s. 273. 
Budynek został zaprojektowany na planie koła, posiadającego dwa ryzality usytuowane na osi. Jeden stanowi joński portyk, drugi zaś absyda. Obiekt przekryty został spłaszczoną kopułą ${ }^{18}$, pokrytą blachą. W cokole kaplicy umieszczono epitafia rodzinne ${ }^{19}$.

Oprócz kaplicy w parku usytuowano niegdyś samotną chatkę jako element romantyczny założenia. Obiekt ten nie zachował się do chwili obecnej.

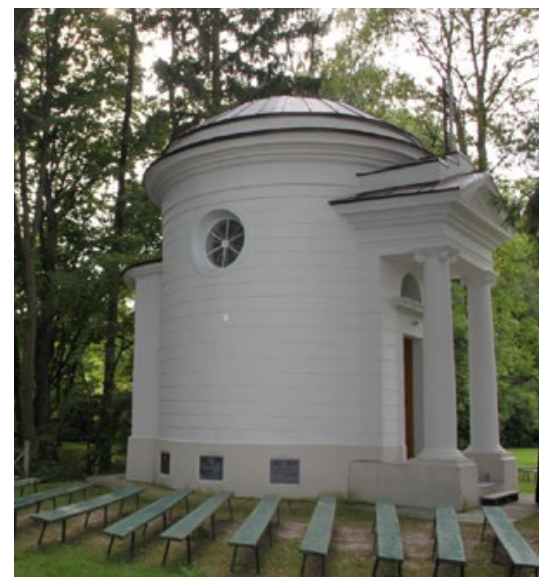

a

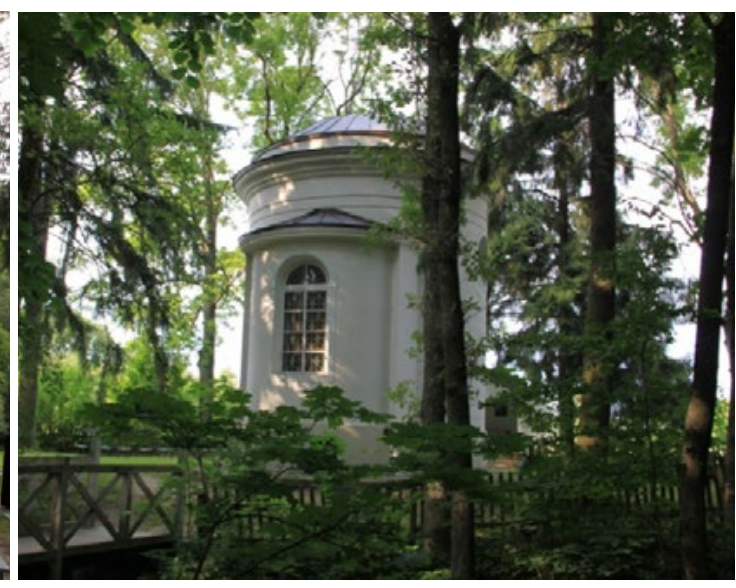

b

Ryc. 8. Romanów, widok na kaplicę, a - kaplica pałacowa. Fot. autor, (2011), b - stan w roku 2010 - widok od strony parku. Fot. autor.

Fig.8. Romanow, views of the chapel, a - the palace chapel, Photo by . author, (2011) $\mathrm{b}-$ the view from the park. Photo by author, (2010)

\section{PODSUMOWANIE}

Romanów pozostawał w rękach rodziny Kraszewskich do 1945 roku. Ostatnimi właścicielkami założenia pałacowo - parkowego były córki Kajetana Kraszewskiego: Maria i Paulina z Kraszewskich Rościszewska ${ }^{20}$.

W roku 1946 majątek Romanów przeszedł na Skarb Państwa, zaś nowym użytkownikiem parku wraz z ruinami pałacu została Nadleśnictwo.

W 1958 roku Wojewódzka Rada Narodowa podjęła decyzję o odbudowie pałacu i utworzenia w budynku muzeum. Prace rekonstrukcyjne trwały do 1962 roku, kiedy to udostępniono obiekt zwiedzającym. Podjazd z rampą, taras z balkonem od strony ogrodu i historyczny układ salonu zrekonstruowano w latach 1987-199121.

W latach 2007-2013 zrealizowany został program pt. Restauracja zespotu dworsko-parkowego w Romanowie będącego siedziba Muzeum Józefa Ignacego Kraszewskiego, będący projektem Regionalnego Programu Operacyjnego Województwa Lubelskiego. Jego wynikiem jest przeprowadzony remont dachu dworu - zmiana pokrycia z blachy płaskiej na drewniany gont, a także przywrócenie historycznego układu lukarn oraz obserwatorium - galerii na dachu.

18 Katalog..., op. cit., s. 37.

19 W cokole kaplicy umieszczono następujące nazwiska :Wojciech Nowomiejski, Zofia Malska z Kraszewskich, Jan Kraszewski, Kajetan Kraszewski, Maria z Rulikowskich Kajetanowa Kraszewska, Krzysztof Kraszewski.

20 R. Aftanazy, Dzieje..., op. cit., s. 123.

$21 \mathrm{http} / / /$ muzeumjik.prv.pl/dane/historia-dworu.html, 9.08.2012. 
W wyniku projektu ogrodzono także całe założenie dworsko - parkowe. Restauracji został poddany także eklektyczny most prowadzący do zespołu. Na potrzeby funkcjonowania muzeum wybudowano także nowy parking. Wartość projektu wynosiła 1965 117,55 PLN²2.

Przeprowadzony projekt wpłynął znacząco na całe założenie dworsko - parkowe. Majątek stanowi wizytówkę regionu, a umiejętności pozyskiwania środków unijnych mogą stanowić bardzo dobry przykład tego jak należy konserwować i dbać o zabytki będące dziedzictwem kulturowym ziem Lubelszczyzny będąc jednocześnie członkiem Wspólnoty Europejskiej.

\section{PIŚMIENNICTWO}

Aftanazy R., Dzieje rezydencji na dawnych kresach Rzeczypospolitej, województwo brzesko - litewskie nowogródzkie, t. 2, Zakład Narodowy im. Ossolińskich, Wrocław 1992

Katalog zabytków sztuki w Polsce, województwo lubelskie, powiat włodawski, T. VIII, z. 18, Instytut Sztuki PAN, 1975

Fijałkowski D., Kseniak M., Parki wiejskie Lubelszczyzny stan ochrona i rewaloryzacja biocenotyczna , PWN, Warszawa 1982

Przesmycka E., Boguszewska K., Bramy i kordegardy w zespołach dworskich i pałacowych województwa lubelskiego - stan zachowania, Teka Komisji Architektury, Urbanistyki i Studiów Krajobrazowych, PAN Lublin, 2011

Petera - Górak J., Kaplice i figury w rezydencjach ziemiańskich i parkach dworskich na Lubelszczyźnie, [w:] Ziemiaństwo na Lubelszczyźnie, Materiały II sesji naukowej zorganizowanej w Muzeum w Zamoyskich w Kozłówce 22-24 mają 2002, opracowała Róża Maliszewska, Muzeum Zamoyskich w Kozłówce 2003,).

Sulmierski F., Chlebowski B., Walewski W., Słownik geograficzny Królestwa Polskiego i innych krajów słowiańskich, Warszawa 1880- 1904,

Stanilewicz A., Dołęgowski H., Prace remontowe przy obiekcie słupy bramne (słupy bramne i dwie wieżyczki), lipiec 2010

Żywicki J., Architektura neogotycka na Lubelszczyźnie, Regionalny Ośrodek Studiów i Ochrony Środowiska Kulturowego w Lublinie idea Media, Lublin 1998

http://muzeumjik.prv.pl/dane/historia-dworu.html, 9.08.2012 r.

http://www.muzeumkraszewskiego.pl/historia-dworu/, 10.10.2015 r.

http://www.muzeumkraszewskiego.pl/wp-content/uploads/2013/06/muzeum_folder_26-06-2013.pdf, 10.10.2015 r.

\section{THE MANOR HOUSE - PARK COMPLEX IN ROMANOW THE HISTORY AND CURRENT STATE OF PRESERVATION}

Summary: The Romanów complex is home of Kraszewski family. At the moment, the historic mansion works as the Museum of Józef Ignacy Kraszewski. The purpose of this article is to present the history and state of preservation of the residential complex, its transformation with special emphasis on objects of landscape architecture.

To the present day two objects of small architecture exist in this residential complex. There are park chapel founded by Constance Mochorowska and eclectic gate dating from the first half of the nineteenth century.

The article will present state of preservation of this objects and descriptions of park buildings that no longer exist: the neo-gothic greenhouse and lonely hut once constituting as an element of the romantic park.

Keywords: Józef Ignacy Kraszewski Museum in Romanov, manor-park, classicism, the EU funds, restauration

$22 \mathrm{http}: / / w w w . m u z e u m k r a s z e w s k i e g o . p l / w p-c o n t e n t / u p l o a d s / 2013 / 06 /$ muzeum_folder_26-06-2013.pdf, 10.10.2015 r. 